\title{
Hasil Belajar Kognitif Peserta Didik Melalui Penerapan Model Pembelajaran Inkuiri Berbantuan Media Simulasi PhET Kelas XI IPA SMA Negeri 1 Anggana Materi Fluida Statis
}

\author{
Rada Fatikasari ${ }^{1 *}$, Benyamin Matius ${ }^{2}$, M. Junus ${ }^{3}$ \\ 1,2,3 Pendidikan Fisika, Fakultas Keguruan dan IImu Pendidikan, \\ Universitas Mulawarman, Samarinda-Indonesia \\ *Email : radaFatikasari96@gmail.com
}

\begin{abstract}
Abstrak
Model pembelajaran inkuiri berbantuan media simulasi PhET adalah suatu tahapan pembelajaran mengikuti langkah-langkah model pembelajaran inkuiri dengan dibantu aplikasi simulasi $P h E T$ sebagai laboratorium virtual. Penelitian ini bertujuan untuk mengetahui rata-rata dan peningkatan hasil belajar kognitif peserta didik melalui model pembelajaran inkuiri berbantuan media simulasi PhET pada materi fluida statik. Penelitian ini dilakukan di SMA Negeri 1 Anggana dengan jumlah sampel sebanyak 30 peserta didik pada kelas XI IPA 1. Pengumpulan data dalam penelitian ini menggunakan teknik tes. Berdasarkan hasil penelitian diperoleh nilai rata-rata hasil belajar kognitif peserta didik sebesar 75 . Hal ini menunjukkan bahwa rata-rata peserta didik mendapatkan nilai dengan kategori baik. Hasil $\mathrm{N}$-Gain diperoleh rata-rata sebesar 69,7 dengan perolehan $47 \%$ untuk kriteria $\mathrm{N}$-Gain sedang dan perolehan $53 \%$ untuk kriteria $\mathrm{N}$-Gain sedang. Hal ini menunjukan bahwa terdapat peningkatan pada hasil belajar kognitif peserta didik kelas XI IPA 1 materi fluida statik dengan kategori $\mathrm{N}$-Gain sedang.
\end{abstract}

Kata kunci : Hasil Belajar Kognitif, Model Pembelajaran Inkuiri, PhET.

\begin{abstract}
The inquiry learning model with the help of PhET simulation media is a learning phase following the steps of the inquiry learning model with the help of the PhET simulation application as a virtual laboratory. This study aims to determine the average cognitive learning outcomes and increase cognitive learning outcomes of students through inquiry learning models that are assisted by PhET simulation media on static fluid material. This research was conducted at SMA Negeri 1 Anggana with a total sample of 30 students of XI IPA 1. Data collection in this study used a test technique. Based on the results of the study obtained an average value of cognitive learning outcomes of students by 75 . This shows that the average student gets a value with a good category. $\mathrm{N}$-Gain results obtained an average of 69.7 with the acquisition of $47 \%$ for high $\mathrm{N}$-Gain Criteria and the acquisition of $53 \%$ for the moderate $\mathrm{N}$-Gain criteria. This shows that there is an increase in cognitive learning outcomes of students of class XI IPA 1 static fluid subject matter with a moderate $\mathrm{N}$-Gain category.
\end{abstract}

Keywords: Cognitive Learning Outcomes, Inquiry Learning Model, PhET.

Article History: Received: 19 Desember 2019

Revised : 27 Januari 2020

Accepted: 6 Januari 2020

Published: 31 Januari 2020

How to cite: Fatikasari, R., Matius, B., dan Junus, M. (2020). Hasil Belajar Kognitif Peserta Didik Melalui Penerapan Model Pembelajaran Inkuiri Berbantuan Media Simulasi PhET Kelas XI IPA SMA Negeri 1 Anggana Materi Fluida Statis, 1(1). pp. 65-72. Retrieved from http://jurnal.fkip.unmul.ac.id/index.php/jpfp/index

Copyright @ Januari 2020, Jurnal Literasi Pendidikan Fisika

\section{PENDAHULUAN}

Pada masa sekarang yaitu Abad 21 merupakan abad dimana informasi banyak tersebar dan teknologi berkembang. Karakteristik abad 21 ditandai dengan semakin bertautnya dunia ilmu pengetahuan dan kemajuan teknologi (BSNP, 2010). Untuk menghadapi perkembangan di abad 21, setiap orang harus memiliki keterampilan berpikir kritis, pengetahuan dan kemampuan literasi digital, literasi informasi, literasi media dan menguasai teknologi informasi dan komunikasi (Frydenberg dan Andone, 2011). Bidang pendidikan 
Hasil Belajar Kognitif...

diharapkan juga dapat mengikuti perkembangan abad 21. Salah satu alternatif agar proses pendidikan bersinergi dengan perkembangan teknologi di Abad 21 adalah pembelajaran yang mengedepankan kemampuan analisis ilmiah diikuti kemampuan penggunaan teknologi masa kini.

Sejalan dengan perkembangan ilmu pengetahuan dan teknologi, fisika sebagai salah satu ilmu yang telah berkembang begitu pesat, baik materi maupun kegunaannya. Kegunaan fisika tidak terbatas pada cabang ilmu pengetahuan alam saja, tetapi juga bidang lain seperti teknologi, elektronika, arsitek, dan sebagainya. Oleh karena itu, fisika merupakan salah satu ilmu yang menarik untuk dikuasai oleh semua peserta didik. Fisika merupakan ilmu yang bertujuan untuk mendidik peserta didik, agar dapat berpikir logis, kritis, memiliki sifat obyektif, disiplin dalam menyelesaikan permasalahan baik dalam berbagai bidang. Fisika merupakan salah satu cabang IPA yang mendasari perkembangan teknologi maju dan konsep hidup harmonis dengan alam, meskipun demikian, masih banyak siswa yang menganggap bahwa fisika merupakan mata pelajaran yang sulit baik dalam penggunaan rumus dan memahami konsep fisika itu sendiri (Budiyanto, 2008).

Berdasarkan hasil observasi dan wawancara dengan guru mata pelajaran Fisika kelas $11 \mathrm{di}$ SMA Negeri 1 Anggana, mata pelajaran fisika masih dianggap susah bagi sebagian peserta didik. Proses pembelajaran fisika dikelas masih berpusat pada guru. Guru masih menggunakan model pembelajaran konvensional menggunakan metode ceramah. Saat proses belajar mengajar di kelas guru langsung mulai memaparkan materi kemudian memberi contoh soal dan selanjutnya mengevaluasi peserta didik dengan cara memberi latihan soal. sehingga peserta didik kurang aktif dalam proses pembelajaran dan kurang termotivasi untuk melakukan tanya jawab sehingga hanya sebagian peserta didik yang memahami dan bertanya saat proses pembelajaran berlangsung.

Hasil wawancara dengan guru Fisika di SMA Negeri 1 Anggana juga memaparkan kendala yang dihadapi guru untuk menggunakan beberapa model pembelajaran yang menuntut keaktifan peserta didik karena kurangnya sarana dan prasarana laboratorium sehingga menyulitkan guru untuk mengajar peserta didik untuk melakukan eksperimen baik dikelas maupun di laboratorium. Hal ini berdampak pada hasil belajar kognitif siswa seperti hasil ulangan harian dan ujian tengah semester peserta didik mata pelajaran Fisika di SMA Negeri 1 Anggana yang masih rendah dan sebagian hasil peserta didik belum mencapai nilai KKM sebesar 75 .

Dalam usaha mendapatkan hasil belajar peserta didik yang baik maka tenaga pendidik harus mempunyai strategi dalam melakukan pembelajaran. Strategi merupakan pola umum rentetan kegiatan yang harus dilakukan untuk mencapai tujuan (Asril, 2011). Faktor-faktor tersebut di atas, seharusnya bisa diatasi dengan menggunakan model pembelajaran yang dapat melibatkan keaktifan siswa dalam proses pembelajaran fisika. Oleh karena itu, hendaknya setiap pendidik terlebih dahulu dapat mempertimbangkan model apa yang tepat digunakan sehingga siswa lebih aktif dalam kegiatan pembelajaran yang pada akhirnya dapat meningkatkan hasil belajar siswa yang masih rendah pada aspek kognitif. Salah satu model pembelajaran yang dapat digunakan untuk meningkatkan aktivitas dan hasil belajar siswa adalah model pembelajaran inkuiri, dimana proses pembelajaran berorientasi pada siswa yang dapat menstimulus siswa untuk aktif dalam kegiatan belajar mengajar. Menurut Basyiruddin dalam Istarani (2012) mengatakan bahwa inkuiri adalah suatu cara penyampaian pelajaran dengan penelaahan sesuatu yang bersifat mencari secara kritis, analitis, dan argumentatif (ilmiah) dengan menggunakan langkah-langkah tertentu menuju suatu kesimpulan. Proses pembelajaran inkuiri dilakukan melalui tahapan-tahapan agar mempermudah guru melaksanakan pembelajaran di kelas dan setiap model pembelajaran tentu terdapat langkah-langkah yang sudah tersusun secara runtut yang digunakan sebagai acuan dalam pelaksanaannya.

Menurut Sanjaya (2010) langkah-langkah proses pembelajaran inkuiri adalah sebagai berikut: Orientasi, Merumuskan masalah, Mengajukan hipotesis, Mengumpulkan data, Menguji hipotesis, Merumuskan kesimpulan. Salah satu solusi karena tidak tersedianya laboratorium yang dapat menunjang 
Hasil Belajar Kognitif...

pembelajaran yang berpusat pada siswa adalah pembelajaran menggunakan media teknologi, khususnya dalam melakukan eksperimen untuk menganalisa gejala fisika ataupun untuk memverifikasi suatu rumusan. Upaya untuk mendukung pembelajaran yang menyesuaikan perkembangan zaman adalah pembelajaran menggunakan media teknologi, salah satunya adalah virtual laboratory. Laboratorium virtual adalah berupa software komputer yang memiliki kemampuan untuk melakukan modeling peralatan komputer secara matematis yang disajikan melalui sebuah simulasi (Purwanti,2012). Salah satu Virtual laboratory yang dapat digunakan pada pembelajaran fisika adalah Physics Education Technology (PhET) (Hendro, Ishafit dan Winarti. 2006). PhET dikembangkan oleh University of Colorado at Boulder Amerika dalam rangka menyediakan simulasi pengajaran dan pembelajaran fisika berbasis laboratorium maya (Virtual Laboratory) yang memudahkan guru dan siswa jika digunakan untuk pembelajaran di ruang kelas. Pembelajaran dengan menggunakan model pembelajaran inkuiri berbantuan media simulasi PhET, peserta didik dapat mengumpulkan informasi dan menguji hipotesis menggunakan laboratorium virtual.

\section{METODE}

Jenis penelitian yang digunakan adalah jenis penelitian kuantitatif pre eksperimental dengan metode One-Group Pretest-Posttest Designs. Pada desain ini sebelum sampel diberikan perlakuan, sampel diberikan pretest terlebih dahulu, kemudian setelah sampel diberikan perlakuan, sampel diberikan posttest. Penelitian ini di laksanakan pada bulan September 2019 semester ganjil tahun pembelajaran 2019/2020 di SMA Negeri 1 Anggana, yang beralamat di Jl. Masjid RT. 06 Desa Anggana kecamatan Anggana kabupaten Kutai Kartanegara. Sampel yang digunakan dalam penelitian ini yaitu kelas XI IPA 1 yang berjumlah 30 peserta didik. Teknik pengambilan sampel dalam penelitian ini adalah salah satu kelas yang di ambil secara purposive sampling. Purposive sampling adalah teknik penentuan sampel dengan pertimbangan tertentu yakni kemampuan siswa yang hampir sama (homogen). Teknik pengumpulan data pada penelitian ini dilakukan dengan teknik tes. Tes yang dilakukan 2 kali yaitu sebelum sampel diberikan perlakuan (pretest) dan setelah sampel diberikan perlakuan (posttest). Soal pretest diberikan kepada peserta didik sebelum dilakukannya model pembelajaran inkuiri berbantuan simulasi PhET dengan jumlah soal sebanyak 7 butir untuk mengetahui tingkat pemahaman peserta didik di awal. Soal posttest diberikan kepada siswa di akhir materi Fluida Statis yang menggunakan model pembelajaran inkuiri berbantuan media simulasi PhET dengan jumlah soal sebanyak 7 butir. Analisis data pada penelitian yang digunakan adalah sebagai berikut :

Nilai Rata-Rata (Mean) : Rata-rata digunakan untuk mengetahui rata-rata nilai hasil belajar kognitif siswa dalam satu kelas dan untuk mengetahui skor rata-rata hasil belajar digunakan rumus:

$$
\bar{X}=\frac{\Sigma \mathrm{X}}{\mathrm{N}}
$$

Dengan $X=$ Rata-rata; $\Sigma X=$ Jumlah/total semua skor; dan $N$ = Banyak siswa (Suharsimi, 2009).

Persentase Hasil Belajar : Untuk mengetahui persentase hasil belajar siswa menggunakan rumus:

$$
\mathrm{P}=\frac{f}{N} \times 100 \%
$$

Dengan $f=$ Frekuensi yang sedang dicari presentasinya; $N=$ Jumlah frekuensi atau banyaknya individu; $P=$ Angka persentase.

Tabel 1. Kriteria Penilaian Hasil Belajar

\begin{tabular}{ccc}
\hline Nilai & Kriteria & Keterangan \\
\hline $85 \leq \mathrm{X} \leq 100$ & A & Baik sekali \\
\hline $75 \leq \mathrm{X}<85$ & B & Baik \\
\hline $65 \leq \mathrm{X}<75$ & C & Cukup \\
\hline $55 \leq \mathrm{X}<65$ & D & Kurang \\
\hline $0 \leq \mathrm{X}<55$ & E & Kurang sekali
\end{tabular}

(Sumber: Fitria, 2015)

$\mathbf{N}$-Gain : Peningkatan yang terjadi sebelum dan sesudah pembelajaran diperhitungkan dengan rumus $\mathrm{N}$-Gain. Menghitung skor Gain yang dinormalisasi berdasarkan rumus menurut Archambault (2008) yaitu: (3)

$$
\mathrm{N}-\text { Gain }=\frac{\text { skor } \text { postest }- \text { skor pretest }}{\text { skor } \text { maks }- \text { skor pretest }} \times 100
$$


Hasil Belajar Kognitif...

Hasil skor Gain Ternormalisasi dibagi dalam tiga kategori yaitu pada tabel 2 .

Tabel 2. Kriteria Gain Ternormalisasi

\begin{tabular}{cc}
\hline Presentase & Klasifikasi \\
$N$-Gain $>70$ & Tinggi \\
\hline $30 \leq N$-Gain $\leq 70$ & Sedang \\
\hline$N$-Gain $<30$ & Rendah
\end{tabular}

(Sumber: Archambault, 2008)

\section{HASIL DAN PEMBAHASAN}

HASIL

\section{Perolehan Data Hasil Penelitian}

Pengambilan data pada penelitian ini dilakukan dengan menggunakan instrumen tes. Tes digunakan untuk mengetahui nilai rata-rata kemampuan awal peserta didik (Pretest) dan nilai rata-rata hasil belajar peserta didik di akhir pembelajaran (Posttest).

\section{Data Hasil Nilai Pretest}

Nilai Pretest peserta didik kelas XI IPA 1 SMA Negeri 1 Anggana diperoleh hasil dengan nilai tertinggi sebesar 51 dan nilai terendah adalah 0 . Dari 30 peserta didik mendapatkan hasil pretest dengan kategori kurang sekali.

Tabel 3. Kriteria Penilaian Hasil Pretest Peserta Didik Kelas XI IPA 1

\begin{tabular}{ccccc}
\hline \multicolumn{1}{c}{ Nilai } & Kriteria & Ket. & $\begin{array}{c}\text { Jml. } \\
\text { Siswa }\end{array}$ & $\begin{array}{c}\text { Perse } \\
\text { ntase }\end{array}$ \\
\hline $85 \leq \mathrm{X} \leq 100$ & A & $\begin{array}{l}\text { Baik } \\
\text { sekali }\end{array}$ & - & - \\
\hline $75 \leq \mathrm{X}<85$ & B & Baik & - & - \\
\hline $65 \leq \mathrm{X}<75$ & C & Cukup & - & - \\
\hline $55 \leq \mathrm{X}<65$ & D & Kurang & - & - \\
\hline $0 \leq \mathrm{X}<55$ & E & $\begin{array}{l}\text { Kurang } \\
\text { sekali }\end{array}$ & 30 & $100 \%$ \\
\hline
\end{tabular}

\section{Data Hasil Nilai Posttest}

Nilai posttest peserta didik kelas XI IPA I diperoleh hasil nilai tertinggi dengan nilai 100 dan hasil terendah dengan nilai 56. Persentase secara keseluruhan yang diperoleh dari data Post-Test peserta didik dapat dilihat pada tabel 4.

Tabel 4. Kriteria Penilaian Hasil Posttest Peserta Didik Kelas XI IPA 1

\begin{tabular}{ccccc}
\hline Nilai & Kriteria & Ket. & $\begin{array}{c}\text { Jml. } \\
\text { Siswa }\end{array}$ & $\begin{array}{c}\text { Persen } \\
\text { tase }\end{array}$ \\
\hline $85 \leq \mathrm{X} \leq 100$ & A & $\begin{array}{l}\text { Baik } \\
\text { sekali }\end{array}$ & 6 & $20 \%$ \\
\hline
\end{tabular}

\begin{tabular}{lclcc}
\hline $75 \leq \mathrm{X}<85$ & B & Baik & 8 & $27 \%$ \\
\hline $65 \leq \mathrm{X}<75$ & C & Cukup & 9 & $30 \%$ \\
\hline $55 \leq \mathrm{X}<65$ & D & Kurang & 7 & $23 \%$ \\
\hline $0 \leq \mathrm{X}<55$ & E & $\begin{array}{l}\text { Kurang } \\
\text { sekali }\end{array}$ & - & - \\
\hline
\end{tabular}

Berdasarkan data pada tabel hasil pretest dan tabel hasil posttest diatas untuk mengetahui persentase perbandingan nilai hasil belajar kognitif peserta didik sebelum dan sesudah pembelajaran melalui penerapan model pembelajaran inkuiri berbantuan media simulasi $P h E T$ dapat disajikan dalam bentuk grafik 1

Grafik 1. Persentase Nilai Hasil Pretest dan Posttest

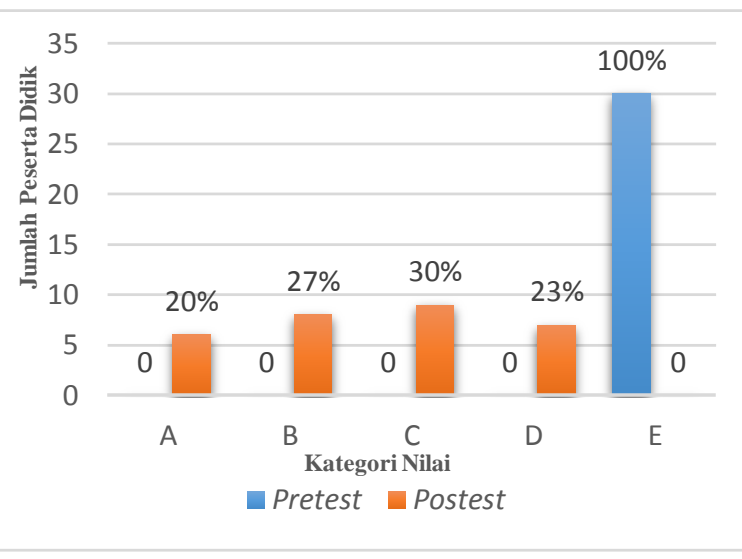

Nilai Rata-Rata (Mean)

Tabel 5. Nilai Rata-Rata Hasil Pretest dan Posttest Kelas XI IPA 1 Jumlah Nilai Rata-rata

\begin{tabular}{ccc} 
& Jumlah Nilai & Rata-rata \\
\hline Pretest & 574,2857 & 19 \\
\hline Posttest & 2241,429 & 75 \\
\hline
\end{tabular}

\section{Analisis N-Gain}

Berdasarkan hasil penelitian yang telah dilakukan maka peneliti dapat menentukan nilai $\mathrm{N}$-Gain untuk mengetahui peningkatan hasil belajar kognitif peserta didik yang diambil dari hasil Pretest dan hasil Posttest. Peningkatan hasil belajar kognitif peserta didik dengan ratarata $\mathrm{N}$-Gain sebesar 69,7 dapat dilihat pada grafik 2. 
Hasil Belajar Kognitif...

Grafik 2. Kriteria N-Gain peserta didik kelas XI IPA 1

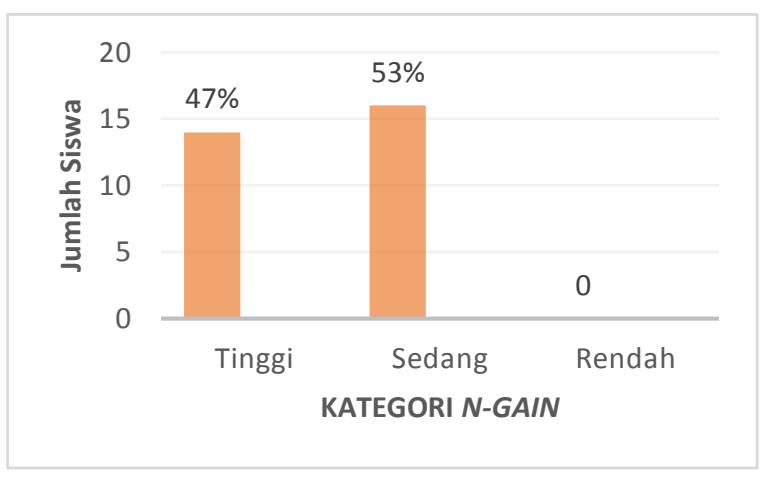

\section{PEMBAHASAN}

Pada penelitian ini akan disampaikan penemuan-penemuan terkait dengan tujuan penelitian, yaitu untuk mengetahui rata-rata hasil belajar kognitif peserta didik melalui penerapan model pembelajaran inkuiri berbantuan media simulasi PhET yang didapatkan dari nilai hasil Posttest sebanyak 7 butir soal essay materi fluida statik, dan untuk mengetahui peningkatan hasil belajar kognitif peserta didik melalui penerapan model pembelajaran inkuiri berbantuan media simulasi $P h E T$ yang dapat dianalisis menggunakan $\mathrm{N}$-Gain dari nilai hasil pretest dan nilai hasil posttest yang dikategorikan sesuai dengan kategori yang digunakan peneliti. Nilai rata-rata hasil belajar kognitif peserta didik diambil dari hasil pretest sebanyak 7 butir soal essay dan hasil posttest sebanyak 7 butir soal essay materi fluida statik. Hasil penelitian dari pretest didapatkan nilai tertinggi yaitu 51 dan nilai terendah adalah 0 . Nilai rata-rata dari hasil pretest sebesar 19 dengan kategori kurang sekali untuk semua peserta didik. Untuk hasil posttest didapatkan nilai tertinggi sebesar 100 dan terendah sebesar 56 dengan rata-rata nilai hasil belajar kognitif peserta didik adalah 75 dengan kategori yang dapat dilihat pada tabel 4.2. Nilai rata-rata hasil belajar kognitif peserta didik masuk dalam kategori baik. Nilai rata-rata hasil belajar kognitif peserta didik dalam kategori baik menunjukkan bahwa penerapan model pembelajaran inkuiri berbantuan media simulasi PhET ini dapat digunakan untuk pembelajaran selanjutnya dikelas. Sejalan dengan pendapat yang dikemukakan oleh Komalasari (2011) yang menyatakan bahwa model pembelajaran inkuiri adalah model pembelajaran yang berupaya menanamkan dasar-dasar berpikir ilmiah pada diri siswa, sehingga dalam proses pembelajaran ini siswa lebih banyak belajar sendiri, mengembangkan kreativitas dalam memahami konsep dan memecahkan masalah. Pada peneitian ini peneliti menggunakan langkahlangkah proses pembelajaran menurut Sanjaya (2010) dengan langkah-langkah yang diawali dengan orientasi, merumuskan masalah, mengajukan hipotesis, mengumpulkan data, menguji hipotesis dan merumuskan masalah.

Pada penelitian ini juga dibantu dengan media simulasi PhET pada pembelajaran materi fluida statik. Penggunaan simulasi ini sangat membantu peserta didik dalam menggali dan mencari informasi dalam proses orientasi sampai dengan merumuskan masalah pada model pembelajaran inkuiri ini. Sejalan dengan pendapat yang dikemukakan oleh Resmiyanto (2009) Physics Education Technology atau PhET merupakan sebuah ikhtiar sistematis yang tanggap jaman terhadap perkembangan teknologi pembelajaran. Simulasi PhET sangat mudah untuk digunakan. Simulasi-simulasi PhET merupakan gambar bergerak (animasi), interaktif dan dibuat seperti layaknya permainan dimana peserta didik dapat belajar dengan melakukan eksplorasi. Simulasi-simulasi tersebut menekankan korespondensi antara fenomena nyata dan simulasi komputer kemudian menyajikannya dalam model-model konseptual fisis yang mudah dimengerti oleh para peserta didik.

Peningkatan hasil belajar kognitif peserta didik dianalisis dengan menggunakan N-Gain, dari hasil perhitungan diperoleh nilai $\mathrm{N}$-Gain dengan kategori tinggi sebesar $47 \%$ dan kategori sedang sebesar $53 \%$. Rata-rata $\mathrm{N}$-Gain Hasil belajar Kognitif peserta didik sebesar 69,7 yang berarti hasil belajar kognitif peserta didik mengalami peningkatan dengan kategori sedang. Hasil penelitian ini menunjukan bahwa pembelajaran melalui penerapan model pembelajaran inkuiri berbantuan media simulasi PhET ini dapat meningkatkan hasil belajar kognitif peserta didik sebesar 69,8 dengan kategori peningkatan sedang. Hasil ini didapatkan karena peserta didik dapat aktif dan menggali informasi menggunakan model pembelajaran inkuiri ini, dengan dibantu oleh media simulasi $P h E T$ peserta didik lebih mudah dan interaktif untuk menggali informasi dan bekerjasama dalam kelompok untuk membuktikan hipotesis yang telah dibuat. 
Hasil Belajar Kognitif...

Sampai menarik kesimpulan dari apa yang peserta didik pelajari.

Hasil penelitian ini sejalan dengan penelitian sebelumnya yang dilakukan oleh Ummi, Elisa, dan Susana (2017) yang berjudul "Penerapan Metode Pembelajaran Inkuiri dengan Media Laboratorium Virtual PhET untuk Meningkatkan Hasil Belajar Siswa Pada Materi Getaran Harmonis" dengan hasil penelitian diperoleh peningkatan hasil belajar peserta didik pada kategori baik dan respon positif pada penggunaan media laboratorium virtual PhET. Hasil penelitian ini juga sejalan dengan penelitian sebelumnya yang dilakukan oleh Prakota (2017), yang berjudul "Pengaruh Model Inkuiri Berbasis Simulasi PhET Terhadap Hasil Belajar Fisika Siswa Kelas XI MIPA SMA Negeri 3 Samarinda Materi Teori Kinetik Gas" dengan hasil penelitian diperoleh peningkatan rata-rata $\mathrm{N}$-Gain peserta didik sebesar 57 yang berarti peserta didik memiliki kriteria peningkatan sedang.

Peningkatan hasil belajar kognitif peserta didik dengan rata-rata $\mathrm{N}$-Gain 69,7 menunjukan bahwa peserta didik kelas XI IPA 1 di SMA Negeri 1 Anggana memiliki kategori hasil belajar kognitif sedang. Dalam penerapanya model pembelajaran inkuiri berbantuan media simulasi $P h E T$ terlaksanan dengan baik dengan memberikan tes awal berupa pretest untuk mengetahui tingkat pemahaman awal peserta didik pada materi fluida statik, penelitian ini terbagi dalam 3 pertemuan untuk proses pembelajaran materi fluida statik, dan untuk mengukur peningkatan hasil belajar kognitif peserta didik dilakukan tes akhir berupa posttest diakhir pertemuan. Pada proses pembelajarannya dengan menggunakan simulasi PhET yang telah terinstal pada laptop disetiap kelompok. Penggunaan simulasi PhET ini sangat membantu peserta didik dalam proses penggalian informasi disetiap langkah-langkah pada model pembelajaran inkuiri. Hal ini sesuai dengan yang dikemukakan oleh Azhar (2014). menyatakan bahwa selain membangkitkan motivasi dan minat siswa, media pembelajaran juga dapat membantu siswa meningkatkan pengetahuan, menyajikan data dengan menarik dan terpecaya, memudahkan penafsiran data dan memadatkan informasi.Oleh karena itu media pembelajaran bermanfaat untuk memperlancar proses interaksi antara guru dan siswa.

Berdasarkan pada hasil penelitian, peningkatan hasil belajar kognitif peserta didik melalui model pembelajaran inkuiri berbantuan media simulasi PhET membuktikan bahwa diperlukanya model pembelajaran yang dapat menumbuhkan keaktifan peserta didik dibandingkan dengan model pembelajaran konvensiaonal dengan berbantuan media pembelajaran yang membuat peserta didik lebih mandiri dan bekerjasama dengan teman sekelompoknya untuk membangun pengetahuan awal peserta didik pada materi yang dipelajari. Seperti yang dikemukakan oleh Swadarma (2011) yang menyatakan bahwa model pembelajaran inkuiri adalah rangkaian kegiatan pembelajaran yang menekankan pada proses berpikir secara kritis dan analitis untuk menemukan sendiri jawaban dari suatu masalah yang dipertanyakan.

Pada penelitian ini peran guru sangatlah penting untuk menciptakan pembelajaran inkuiri yang ideal. Pada penerapanya dikelas XI IPA 1, peserta didik terlibat langsung dan saling berdiskusi terkait permasalahan yang terdapat pada LKPD, peserta didik masih ada yang memerlukan adaptasi terhadap langkah-langkah pada pembelajaran inkuiri dan dengan penggunaan media simulasi $P h E T$ ini. Disinilah peran guru sangat dibutuhkan untuk menjadi fasilitator dan motivator untuk peserta didik agar tujuan pembelajaran dapat tercapai, dan dapat meningkatkan pemahaman peserta didik pada materi fluida statik. Hal ini sejalan dengan pendapat yang dikemukakan oleh Trianto (2009) yang menyatakan bahwa untuk menciptakan kondisi pembelajran inkuiri yang ideal, peranan guru adalah sebagai motivator, member rangsangan agar siswa aktif dan gairah berfikir. Fasilitator, menunjukkan jalan keluar jika siswa mengalami kesulitan. Penanya, menyadarkan siswa dari kekeliruan yang mereka buat. Administrator, bertanggungjawab terhadap seluruh kegiatan kelas. Pengarah, memimpin kegiatan siswa untuk mencapai tujuan yang diharapkan. Manajer, mengelola sumber belajar, waktu, dan organisasi kelas. Reward, memberi penghargaan pada prestasi yang dicapai siswa.

Berdasarkan uraian diatas, hasil penelitian menunjukan bahwa hasil belajar kognitif peserta didik meningkat dengan kategori sedang pada materi fluida statik di kelas XI IPA 1 melalui 
Hasil Belajar Kognitif...

penerapan model pembelajaran inkuiri berbantuan media simulasi PhET. Namun tidak semua penelitian berjalan sesuai dengan yang diinginkan, terdapat beberapa kendala-kendala yang dialami oleh peneliti, seperti pembagian waktu disetiap langkah-langkahnya, dan ketersediaan laptop untuk kelompok yang telah terinstal aplikasi simulasi PhET.

\section{PENUTUP}

Nilai rata-rata hasil belajar kognitif peserta didik melalui penerapan model pembelajaran inkuiri berbantuan media simulasi $P h E T$ sebesar 75 , yang berarti nilai rata-rata hasil belajar kognitif peserta didik dalam kategori baik. Penggunaan model pembelajaran inkuiri berbantuan media simulasi Phet dapat meningkatkan hasil belajar kognitif peserta didik, berdasarkan pada hasil $\mathrm{N}$-Gain peserta didik dengan rata-rata $N$-Gain sebesar 69.7 yang berarti hasil belajar kognitif peserta didik mengalami peningkatan dengan kategori sedang. Dengan perolehan kriteria $N$-Gain tinggi sebesar $47 \%$ dan perolehan $N$-Gain sedang sebesar $53 \%$.

Dalam pelaksanaanya sebaiknya memperhatikan durasi waktu pembelajaran agar tidak ada langkah pembelajaran yang terlewat. Untuk penggunaan aplikasi simulasi PhET dengan pembagian kelompok lebih banyak dengan peserta didik 3-4 orang, agar peserta didik lebih bisa menggali informasi dan bekerjasama dalam kelompok dengan baik.

\section{DAFTAR PUSTAKA}

Archambault, J. (2008). The Effect of Developing Kinematics Concepts Graphically Pior to introducing Algebraic Problem Solving techniques. Action Research Required for the Master of Natural Science Degree with Concentration in Physics. Arizona State University.

Asril, Z. (2011). Microteaching Disertai dengan Pedoman Pengalaman Lapangan. Jakarta: PT Rajagrafindo Persada.

Azhar, A. (2014). Media Pembelajaran. Diakses pada tanggal 26 Maret 2019 dari http://mazguru.wordpress.com/2012/04/19/ ayo-manfaatkan-laboratoriumvirtual/.
BSNP. (2010). Paradigma Pendidikan Nasional Abad XXI. Jakarta: BSNP.

Budiyanto, J. (2008). Fisika Untuk SMA/MA Kelas XII. Jakarta: Pusat Perbukuan Departemen Pendidikan Nasional.

Fitria, N. (2015). Penerapan Metode Inkuiri Terbimbing Berbantuan Media PhET Sebagai Upaya Meningkatkan Minat dan Hasil Belajar Fisika pada Siswa Kelas $X$ di SMA Negeri 2 Samarinda Tahun Ajaran 2014/2015 (Materi Listrik Dinamis). Skripsi, tidak dipublikasikan. Universitas Mulawarman.

Frydenberg, M., \& Andone, D. (2011). Learning for 21st Century Skills, 314-318.

Hendro, K., Ishafit, \& Winarti. (2006). Penentuan Konstanta Planck menggunakan Perangkat Lunak Physics Education Technology PhET. (Jurnal). Yogyakarta: Universitas Ahmad Dahlan.

Prakota, I. (2017). "Pengaruh Model Inkuiri Berbasis Simulasi PhET terhadap hasil Belajar Fisika Siswa kelas XI MIPA SMA Negeri 3 Samarinda materi Teori Kinetik Gas. Skripsi, tidak dipublikasikan. Universitas Mulawarman.

Istarani. (2012). 58 Model Pembelajaran Inovatif. Medan: Media Persada.

Komalasari, K. (2011). Pembelajaran Kontekstual, Konsep dan Aplikasi, $K u a l i t a t i f$ dan $R \& D$. Alfabeta: Bandung.

PhET Simulation Team. (2019). Facilitation Strategies for Inquiry-based, In-class Activities using PhET Simulations. United States: University of Colorado Boulder.

Purwanti, W. (2012). Pemanfaatan Laboratorium Virtual pada Pembelajaran IPA. Pelatihan Digitalisasi Perangkat dan Media Pembelajaran IPA Untuk Meningkatkan Kualitas Pembelajaran di Era Baru" di SMP 3 Muhammadiyah Depok. Skripsi, tidak dipublikasikan. Universitas Negeri Yogyakarta.

Resmiyanto, R. (2009). PhET Simulasi Fisika untuk Membantu Pembelajaran di Kelas. Diakses tanggal 26 Maret 2019 dari http://rachmadresmi.blogspot.com/2009/03 /phet-simulasi-fisika-untuk-membantu-html

Sanjaya, W. (2010). Strategi Pembelajaran Berorientasi. Standar Proses Pendidikan. Kencana Prenada Media Group: Jakarta.

Suharsimi, A. (2009). Dasar-Dasar Evaluasi Pendidikan (Edisi Revisi). Jakarta: Bumi 
Aksara.

Swadarma, D. (2011). Penerapan Mind Mapping dalam Kurikulum Pembelajaran. Gramedia: Jakarta.

Trianto. (2009). Mendesain model pembelajaran inovatif-progresif. Jakarta: Kencana.

Ummi, R., Elisa K., dan Susana. (2017). Penerapan Metode Pembelajaran Inkuiri dengan Media Laboratorium virtual (PhET) untuk Meningkatkan Hasil Belajar Siswa pada Materi Getaran Harmonis. Skripsi, tidak dipublikasikan. Universitas Syiah Kuala. 